\title{
Y-chromosome DNA haplotypes in human samples from Bahia, Brazil
}

\author{
M.V. Santos ${ }^{\mathrm{a}}$, M. Carvalho ${ }^{\mathrm{b}}$, M.J. Anjos ${ }^{\mathrm{b}}$, L. Andrade ${ }^{\mathrm{b}}$, V. Lopes ${ }^{\mathrm{b}}$, \\ F. Corte-Real ${ }^{\mathrm{a}, \mathrm{b}}$, D.N. Vieira ${ }^{\mathrm{a}, \mathrm{b}}$, M.C. Vide ${ }^{\mathrm{b}, *}$ \\ ${ }^{\mathrm{a}}$ Faculty of Medicine, University of Coimbra, Coimbra, Portugal \\ ${ }^{\mathrm{b}}$ Institute Nacional de Medicina Legal, Delegação de Coimbra, Serviço de Genética Forense, \\ Largo da Sé Nova, 3000-213 Coimbra, Portugal
}

\begin{abstract}
Background: The Y-chromosome polymorphisms have a great value to population genetic studies and evolutionary aspects since these markers show high levels of heterogeneity within and between populations, permitting the geographical distribution and ancestry of patrilineages to be evaluated. They complement the autosomal STRs and mtDNA matrilineage information. Y-linked STRs remain stable in given paternal lineages over many generations so they are useful for identification in forensic cases, namely in criminal stain with male/female contributions. Methods: In this study, we report Y-chromosome haplotypes in a population sample with 68 unrelated males blood donors from Bahia state (Northeastern Brazil). The Y-STRs (DYS19, DYS389 I/II, DYS390 and DYS393) were determined after PCR pentaplexing with an automatic ABI sequencer. Results: In the Bahia population, we observed 47 different Y-chromosome haplotypes, of which 37 Y-haplotypes were unique. Only two Y-types were present in more than two persons. The most significant values of gene diversity were found in the markers DYS390, DYS389 II and DYS19 in decreasing order. The haplotype diversity value of the population studied was of 96.62. Conclusion: Comparing this Brazilian population with other Brazilian, Portuguese and African populations, we observed that the Bahia population has a similar haplotype diversity value to other Brazilian and Portuguese populations.
\end{abstract}

(C) 2003 Elsevier Science B.V. All rights reserved.

Keywords: Y-STRs; Brazil population; Gene diversity; Y-chromosome haplotype diversity

\footnotetext{
" Corresponding author. Tel.: +351-239-854-230; fax: +351-239-820-549.

E-mail address: mcvide@ci.uc.pt (M.C. Vide).
} 
Table 1

Haplotypes and haplotypic frequency of the population studied

\begin{tabular}{|c|c|c|c|c|c|c|c|}
\hline Haplotypes & DYS19 & DYS389 I & DYS389 II & DYS390 & DYS393 & $\begin{array}{l}\text { Observed } \\
\text { number }\end{array}$ & $\begin{array}{l}\text { Haplotype } \\
\text { frequency }\end{array}$ \\
\hline H1 & 13 & 10 & 17 & 13 & 23 & 1 & 0.01 \\
\hline $\mathrm{H} 2$ & 13 & 10 & 18 & 13 & 23 & 1 & 0.01 \\
\hline H3 & 13 & 10 & 18 & 14 & 24 & 1 & 0.01 \\
\hline $\mathrm{H} 4$ & 13 & 10 & 19 & 12 & 24 & 1 & 0.01 \\
\hline H5 & 13 & 11 & 16 & 13 & 24 & 1 & 0.01 \\
\hline H6 & 13 & 11 & 19 & 12 & 24 & 1 & 0.01 \\
\hline $\mathrm{H} 7$ & 13 & 9 & 17 & 13 & 24 & 1 & 0.01 \\
\hline $\mathrm{H} 8$ & 14 & 10 & 16 & 13 & 23 & 5 & 0.07 \\
\hline H9 & 14 & 10 & 16 & 12 & 24 & 2 & 0.03 \\
\hline $\mathrm{H} 10$ & 14 & 10 & 16 & 13 & 24 & 10 & 0.15 \\
\hline H11 & 14 & 10 & 16 & 13 & 25 & 1 & 0.01 \\
\hline $\mathrm{H} 12$ & 14 & 10 & 17 & 12 & 21 & 1 & 0.01 \\
\hline H13 & 14 & 10 & 17 & 12 & 22 & 1 & 0.01 \\
\hline H14 & 14 & 10 & 17 & 12 & 23 & 1 & 0.01 \\
\hline H15 & 14 & 10 & 17 & 13 & 24 & 2 & 0.03 \\
\hline H16 & 14 & 11 & 15 & 12 & 24 & 1 & 0.01 \\
\hline H17 & 14 & 11 & 16 & 13 & 24 & 1 & 0.01 \\
\hline $\mathrm{H} 18$ & 14 & 11 & 17 & 15 & 21 & 1 & 0.01 \\
\hline H19 & 14 & 9 & 16 & 13 & 23 & 1 & 0.01 \\
\hline $\mathrm{H} 20$ & 14 & 9 & 16 & 13 & 24 & 2 & 0.03 \\
\hline $\mathrm{H} 21$ & 14 & 9 & 16 & 13 & 25 & 1 & 0.01 \\
\hline $\mathrm{H} 22$ & 14 & 9 & 17 & 12 & 22 & 1 & 0.01 \\
\hline $\mathrm{H} 23$ & 14 & 9 & 17 & 13 & 24 & 1 & 0.01 \\
\hline $\mathrm{H} 24$ & 15 & 10 & 15 & 12 & 24 & 1 & 0.01 \\
\hline $\mathrm{H} 25$ & 15 & 10 & 16 & 12 & 22 & 1 & 0.01 \\
\hline H26 & 15 & 10 & 16 & 13 & 22 & 1 & 0.01 \\
\hline $\mathrm{H} 27$ & 15 & 10 & 16 & 12 & 23 & 2 & 0.03 \\
\hline $\mathrm{H} 28$ & 15 & 10 & 16 & 13 & 23 & 2 & 0.03 \\
\hline H 29 & 15 & 10 & 16 & 13 & 24 & 2 & 0.03 \\
\hline H30 & 15 & 10 & 17 & 14 & 21 & 1 & 0.01 \\
\hline H31 & 15 & 10 & 17 & 14 & 22 & 1 & 0.01 \\
\hline H32 & 15 & 10 & 17 & 13 & 23 & 1 & 0.01 \\
\hline H33 & 15 & 10 & 18 & 13 & 21 & 1 & 0.01 \\
\hline H34 & 15 & 10 & 18 & 13 & 22 & 1 & 0.01 \\
\hline H35 & 15 & 10 & 19 & 13 & 21 & 1 & 0.01 \\
\hline H36 & 15 & 11 & 15 & 13 & 23 & 1 & 0.01 \\
\hline H37 & 15 & 11 & 17 & 13 & 23 & 1 & 0.01 \\
\hline H38 & 15 & 9 & 14 & 13 & 24 & 2 & 0.03 \\
\hline H39 & 15 & 9 & 16 & 12 & 24 & 2 & 0.03 \\
\hline $\mathrm{H} 40$ & 15 & 9 & 16 & 13 & 24 & 1 & 0.01 \\
\hline H41 & 15 & 9 & 17 & 14 & 22 & 1 & 0.01 \\
\hline $\mathrm{H} 42$ & 15 & 9 & 17 & 12 & 23 & 1 & 0.01 \\
\hline H43 & 15 & 9 & 18 & 13 & 22 & 1 & 0.01 \\
\hline H44 & 16 & 10 & 16 & 14 & 23 & 1 & 0.01 \\
\hline H45 & 16 & 10 & 17 & 13 & 22 & 1 & 0.01 \\
\hline H46 & 16 & 11 & 17 & 12 & 24 & 1 & 0.01 \\
\hline H47 & 16 & 11 & 18 & 13 & 21 & 1 & 0.01 \\
\hline
\end{tabular}


Table 2

Number of alleles, gene frequency and diversity

\begin{tabular}{|c|c|c|c|c|c|c|c|c|c|c|c|c|c|c|c|c|c|c|c|c|c|c|}
\hline & \multicolumn{4}{|l|}{ DYS19 } & \multicolumn{3}{|c|}{ DYS389I } & \multicolumn{6}{|c|}{ DYS389II } & \multicolumn{5}{|c|}{ DYS390 } & \multicolumn{4}{|c|}{ DYS393 } \\
\hline Alleles & 13 & 14 & 15 & 16 & 9 & 10 & 11 & 14 & 15 & 16 & 17 & 18 & 19 & 21 & 22 & 23 & 24 & 25 & 12 & 13 & 14 & 15 \\
\hline $\begin{array}{c}\text { Individuals } \\
\text { number }\end{array}$ & 7 & 32 & 25 & 4 & 15 & 43 & 10 & 2 & 3 & 36 & 18 & 6 & 3 & 6 & 9 & 17 & 33 & 3 & 17 & 45 & 5 & 1 \\
\hline $\begin{array}{l}\text { Gene } \\
\text { frequency }\end{array}$ & $\begin{array}{l}0.103 \\
y\end{array}$ & 0.471 & 0.368 & 0.059 & 0.221 & 0.632 & 0.147 & 0.029 & 0.044 & 0.530 & 0.265 & 50.088 & 0.044 & +0.088 & 0.132 & 0.250 & 0.485 & 0.044 & 0.250 & 0.662 & 0.074 & 0.015 \\
\hline $\begin{array}{l}\text { Different } \\
\text { alleles } \\
\text { number }\end{array}$ & 4 & & & & & 3 & & & & & 6 & & & 5 & & & & & 4 & & & \\
\hline $\begin{array}{l}\text { Gene } \\
\text { diversity }\end{array}$ & 63.90 & & & & & 53.80 & & & & & 64.66 & & & 68.50 & & & & & 50.01 & & & \\
\hline
\end{tabular}

diversity 


\section{Introduction}

The Brazilian population is composed of individuals from different ethnic origins varying according to the geographic region. In Bahia state (Northeastern Brazil), the contribution of three groups is evident: Ameridian, European (namely Portuguese) and African, especially from the Northwest region. In this work, we show the study of the Ychromosome haplotypes in a sample population from Bahia and the comparative results with other populations.

\section{Material and methods}

Bloodstains obtained from 68 unrelated voluntary donors were submitted at Chelex 100 $[1,2]$. The samples, after purification, were quantified using Human DNA Quantitation kit QuantiBlot $^{\mathrm{TM}}[3]$.

The loci DYS19, DYS389 I, DYS389 II, DYS390, DYS393 were amplified in a PCR pentaplex format using a Perkin Elmer 9600 thermal cycler according to Gusmão et al. [4].

The separation was carried out by capillary electrophoresis on an ABI PRISM 310 Genetic Analyser instrument performed in Performance Optimised Polymer sieving medium (POP4 ${ }^{\mathrm{TM}} ; 1$-ml syringe).

The fragment size was collected using ABI PRISM Collection Software application, with the module GS POP4 and GeneScan ${ }^{\mathrm{TM}} 500$ (Rox) internal lane size standard.

Table 3

Comparison of the gene and haplotype diversity between populations

\begin{tabular}{|c|c|c|c|c|c|c|c|c|}
\hline \multirow[t]{2}{*}{ Y-STRs } & \multicolumn{5}{|c|}{ Gene diversity } & \multirow{2}{*}{$\begin{array}{l}\text { Individuals } \\
\text { number }\end{array}$} & \multirow{2}{*}{$\begin{array}{l}\text { Haplotypes } \\
\text { number }\end{array}$} & \multirow{2}{*}{$\begin{array}{l}\text { Haplotype } \\
\text { diversity }\end{array}$} \\
\hline & DYS19 & DYS389I & DYS389II & DYS390 & DYS393 & & & \\
\hline Bahia/Brazil & 63.90 & 53.80 & 64.66 & 68.50 & 50.10 & 68 & 47 & 96.62 \\
\hline São Paulo/Brazil [9] & 58.39 & 56.74 & 55.95 & 55.01 & 46.62 & 53 & 33 & 97.17 \\
\hline Amazonas/Brazil [9] & 65.75 & 47.54 & 63.07 & 68.96 & 29.11 & 42 & 32 & 98.37 \\
\hline $\begin{array}{l}\text { Portuguese } \\
\quad \text { Population [10] }\end{array}$ & 59.61 & 50.58 & 47.34 & 66.56 & 51.82 & 119 & 63 & 96.43 \\
\hline $\begin{array}{c}\text { Northwest African } \\
\text { Population [11] }\end{array}$ & 44.80 & 49.60 & 51.45 & 63.70 & 28.70 & 185 & 56 & 87.61 \\
\hline
\end{tabular}

Table 4

Matrix of genetic distances

\begin{tabular}{llllll}
\hline & $\begin{array}{l}\text { Bahia/ } \\
\text { Brazil }\end{array}$ & $\begin{array}{l}\text { Amazonas/ } \\
\text { Brazil }\end{array}$ & $\begin{array}{l}\text { S. Paulo/ } \\
\text { Brazil }\end{array}$ & $\begin{array}{l}\text { Northwest } \\
\text { Africa }\end{array}$ & Portugal \\
\hline Bahia/Brazil & - & 0.0380 & 0.0269 & 0.2750 & 0.2837 \\
Amazonas/Brazil & 0.0380 & - & 0.0571 & 0.1893 & 0.3068 \\
S. Paulo/Brazil & 0.0269 & 0.0571 & - & 0.2629 & 0.2516 \\
Northwest Africa & 0.2750 & 0.1893 & 0.2629 & - & 0.4315 \\
Portugal & 0.2837 & 0.3068 & 0.2516 & 0.4315 & - \\
\hline
\end{tabular}




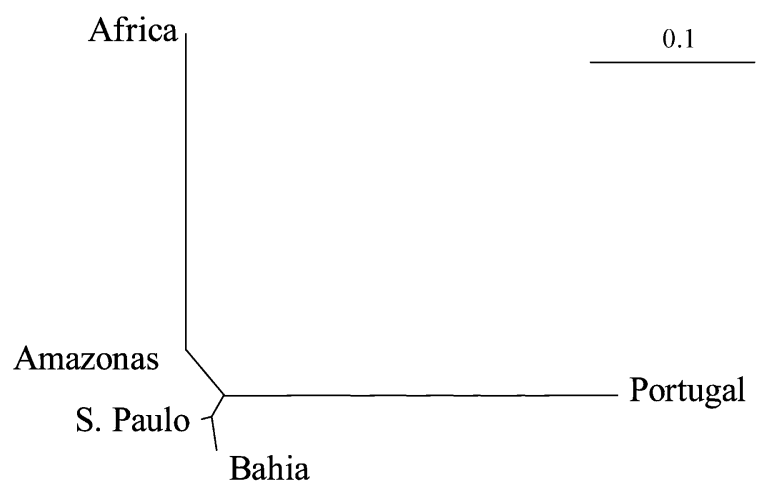

Fig. 1. Phylogenetic tree of the populations from Brazil, Portugal and Northwest Africa.

The repeat nomenclature follows that of Kayser et al. [5], Rolf et al. [6] and Gill et al. [7].

Allele and haplotype frequencies were estimated by gene counting. Gene and haplotype diversity were computed for each locus according to Nei [8].

\section{Results}

In the 68 males from Bahia, we observed 47 different Y-chromosome haplotypes, of which 37 Y-haplotypes were unique. Only two Y-types were present in more than two persons (Table 1). The most significant values of gene diversity were found in the markers DYS390, DYS389 II and DYS19 in decreasing order (Table 2). The haplotype diversity value of the population studied was of 96.62 (Table 3). The comparative studies are represented in Tables 3 and 4 and Fig. 1.

\section{Discussion}

Comparing this Brazilian population with other Brazilian, Portuguese and African populations, we observed that the Bahia population has a similar haplotype diversity value to other Brazilian and Portuguese populations, but a higher value when comparing with the Northwest African populations.

As expected, the genetic distances were lower between Brazilian populations. These results confirm the importance of the Y-STRs, being highly polymorphic markers and informative of the relationships between populations.

\section{Acknowledgements}

We are grateful to $\mathrm{CNPq} /$ Brazil for financial support to the student. 


\section{References}

[1] P.S. Walsh, D.A. Metzger, R. Higuchi, Chelex 100 as a medium for simple extraction of for PCR-based typing from forensic material, BioTechniques 10 (1991) 506-513.

[2] B. Budowle, et al., Simple protocols for typing forensic biological evidence: chemiluminescent detection for human DNA quantitation and restriction fragment length polymorphism (RFLP) analyses and manual typing of polymerase chain reaction (PCR) amplified polymorphisms, Electrophoresis 16 (1995) 1559-1567.

[3] P.S. Walsh, J. Varlaro, R. Reynolds, A rapid chemiluminescent method for quantitation of human DNA, Nucleic Acids Res. 20 (1992) 5061-5065.

[4] L. Gusmão, et al., Robustness of the Y-STRs DYS19, DYS 389 I and II, DYS390 and DYS393: optimization of a PCR pentaplex, Forensic Sci. Int. 106 (1999) 163-172.

[5] M. Kayser, et al., Evaluation of Y-chromosomal STRs: a multicenter study, Int. J. Leg. Med. 110 (1997) $125-133$.

[6] B. Rolf, et al., Polymorphism at the tetranucleotide repeat locus DYS389 in ten populations reveals strong geographic clustering, Eur. J. Hum. Genet. 6 (1998) 583-588.

[7] P. Gill, et al., DNA commission of the international society of forensic genetics: recommendations on forensic analysis using Y-chromosome STRs, Int. J. Leg. Med. 114 (2001) 305-309.

[8] M. Nei, Molecular Evolutionary Genetics, Columbia Univ. Press, New York, 1987.

[9] F. Corte-Real, et al., Chromosome Y STRs analysis and evolutionary aspects for Portuguese spoken countries, in: G.F. Sensabaugh, P.J. Lincoln, B. Olaisen (Eds.), Progress in Forensic Genetics, vol. 8, Elsevier, Amsterdam, 2000, pp. 272-274.

[10] A. Carracedo, et al., Results of a collaborative study of the EDNAP group regarding the reproducibility and robustness of the Y-chromosome STRs DYS19, DYS389 I and II, DYS 390 and DYS 393 in a PCR pentaplex format, Forensic Sci. Int. 119 (2001) 28-41.

[11] E. Bosch, et al., Y chromosome STR haplotypes in four populations from Northwest Africa, Int. J. Leg. Med. 114 (2000) 36-40. 